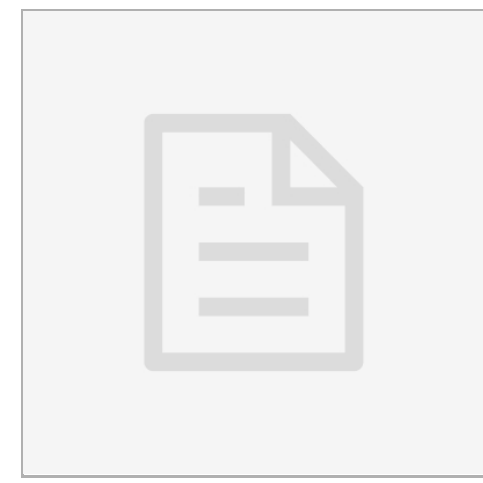

OCT 14, 2019

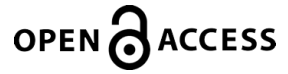

DOI:

dx.doi.org/10.17504/protocol s.io.768hrhw

Protocol Citation: Igem Dusseldorf 2019. Isolation of total RNA from Synechocystis. protocols.io

https://dx.doi.org/10.17504/p rotocols.io. $768 \mathrm{hrhw}$

License: This is an open access protocol distributed under the terms of the Creative Commons Attribution License, which permits unrestricted use, distribution, and reproduction in any medium, provided the original author and source are credited

Protocol status: Working We use this protocol and it's working

Created: Oct 14, 2019

Last Modified: Oct 14, 2019

PROTOCOL integer ID: 28608

\section{(3) Isolation of total RNA from Synechocystis}

Igem Dusseldorf ${ }^{1}$

${ }^{1}$ Heinrich-Heine Universität Düsseldorf<smiles>C1CCCCCC1</smiles>
Igem Dusseldorf

\section{ABSTRACT}

Isolation of total RNA from Synechocystis sp. PCC 6803 Can be used for further work, like qPCR Always work fast, with ice and RNase-free (wear gloves!)

- PGTX solution (100 mL)

- $39.6 \mathrm{~g}$ phenol, $6.9 \mathrm{~mL}$ glycerol, $0.1 \mathrm{~g}$ hydroxyquinoline, $0.58 \mathrm{~g}$ EDTA, $0.8 \mathrm{~g}$ $\mathrm{NaOAc}, 9.5 \mathrm{~g}$ guanidine thiocyanate,

$4.6 \mathrm{~g}$ guanidine hydrochloride

- PGTX contains phenol, wear safety gear and gloves

- Synechocystis culture

- Chloroform/IAA

- IPA + NaOAc (in a specific amount)

- 1 vol. IPA or 3 vol. EtOH and NaOAc 30:1 or 10:1

\section{Start}

Centrifuge $5 \mathrm{ml}$ of culture ( $\left(\mathrm{OD}_{750}\right.$ of $\left.\sim 1\right)$ for 5 minutes at maximum speed $\left(\mathrm{T}=4^{\circ} \mathrm{C}\right)$ Discard supernatant. Resuspend cyanobacterial pellet in the remaining water ( 1 $\mathrm{ml}$ ). Transfer to a fresh $2 \mathrm{ml}$ tube (RNase-free). Spin down $1 \mathrm{~min}$ at maximum speed. Discard remaining supernatant. resuspend pellet in $1 \mathrm{ml} \mathrm{PGTX}$ solution. Flash freeze and store at $-80^{\circ} \mathrm{C}$ for later extraction, or proceed with the next step.

\section{Extract}

Heat samples at $95^{\circ} \mathrm{C}$ for 5 minutes in a shaking heat block. Vortex samples from time to time to ensure complete lysis.

Place samples on ice for 5 minutes.

Add $700 \mu \mathrm{l}$ Chloroform/IAA. Vortex sample until it is opaque. Incubate at RT for 10 min, vortexing from time to time.

Centrifuge samples at maximum speed for 10 minutes to seperate phases. Transfer aqueous phase $(600 \mu \mathrm{l})$ to a fresh tube (RNase-free).

Add 1 vol. $(600 \mu l)$ Chloroform/IAA. Mix well by vortexing. Centrifuge 10 minutes at 
maximum speed. Transfer aqueous phase $(500 \mu \mathrm{l})$ to a fresh tube (RNase-free).

\section{Precipitation}

Add $517 \mu \mathrm{l}$ IPA $+\mathrm{NaOAc}$ to the samples. Mix well. Precipate over weekend at $-20^{\circ} \mathrm{C}$. Also possible: $1 \mathrm{~h}$ at $-80^{\circ} \mathrm{C}$ or over night at $-20^{\circ} \mathrm{C}$.

Centrifuge precipitated sample at $4^{\circ} \mathrm{C}$ and maximum speed for at least $30 \mathrm{~min}$. Remove supernatant, making sure not to disrupt the RNA pellet. Wash pellet with $70 \% \mathrm{EtOH}(300 \mu \mathrm{l})$. Centrifuge for 15 minutes, $4^{\circ} \mathrm{C}$ at maximum speed. Completely remove supernatant. Dry at RT for $\sim 5$ minutes. Do not overdry! Resuspend pellet in $40 \mu \mathrm{l}$ pure, RNase-free water. Store at $-80^{\circ} \mathrm{C}$. 